\title{
Paideusis
}

\section{Resistance Reconceptualized}

\section{Valda Kathleen Leighteizer}

Volume 15, Number 2, 2006

URI: https://id.erudit.org/iderudit/1072678ar

DOI: https://doi.org/10.7202/1072678ar

See table of contents

Publisher(s)

Canadian Philosophy of Education Society

ISSN

0838-4517 (print)

1916-0348 (digital)

Explore this journal

Cite this article

Leighteizer, V. (2006). Resistance Reconceptualized. Paideusis, 15(2), 27-35. https://doi.org/10.7202/1072678ar

\section{Article abstract}

In vernacular understandings or conversations about resistance as it occurs with students in public schools, it is frequently viewed as a negative action or set of behaviours to be changed or curtailed. This paper puts forward an argument that allows for the possibility of seeing moments of resistance as something to be recognized and celebrated with students. I do not suggest that resistance must always or only be viewed in this manner, but rather that it might be viewed thus, and thereby allow for multiple understandings of an action such as resistance.

Beginning with my own hegemonic understanding of resistance as a necessarily bad/undesirable characteristic or behaviour, I then build on Foucault's relational approach to understanding power (and its operations), leading then to a discussion of student engagement as also a relational process and one that has more than one possible form. By offering a possibility of understanding student engagement as a process that works both within and outside the structures that produce and maintain the White, middle class, heterosexual, abled, Christian, male child as the defacto subject of schooling, I build an argument that opens a more fluid conception of resistance than the necessarily negative action it is often perceived to be. (c) Valda Kathleen Leighteizer, 2006

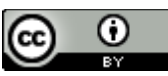

This document is protected by copyright law. Use of the services of Érudit (including reproduction) is subject to its terms and conditions, which can be viewed online.

https://apropos.erudit.org/en/users/policy-on-use/ 


\title{
Resistance Reconceptualized
}

\author{
VALDA K. LEIGHTEIZER \\ Mount Saint Vincent University, Canada
}

In vernacular understandings or conversations about resistance as it occurs with students in public schools, it is frequently viewed as a negative action or set of behaviours to be changed or curtailed. This paper puts forward an argument that allows for the possibility of seeing moments of resistance as something to be recognized and celebrated with students. I do not suggest that resistance must always or only be viewed in this manner, but rather that it might be viewed thus, and thereby allow for multiple understandings of an action such as resistance.

Beginning with my own hegemonic understanding of resistance as a necessarily bad/undesirable characteristic or behaviour, I then build on Foucault's relational approach to understanding power (and its operations), leading then to a discussion of student engagement as also a relational process and one that has more than one possible form. By offering a possibility of understanding student engagement as a process that works both within and outside the structures that produce and maintain the White, middle class, heterosexual, abled, Christian, male child as the de facto subject of schooling, I build an argument that opens a more fluid conception of resistance than the necessarily negative action it is often perceived to be.

\section{Introduction and Background}

For many years I viewed student resistance as a particular, and usually negative or undesirable, kind of action or behaviour, something to be avoided wherever possible. If or when it did arise, resistance required an immediate response to end the activity or action of the student. I treated resistance as a challenge to either my authority or my knowledge and my task was to shut it down. As I was reading, writing, and thinking about teaching for social justice, I began to consider the inter-connections of complex processes such as the operations of power relations, notions of student engagement, and the student "body". I found myself re-thinking my understandings of resistance, such that I now perceive that resistance is not always or necessarily a negative action. Resistance can, in some instances, be something to be cherished, nurtured, or celebrated with a student.

When I began teaching, I held some narrow definitions of what constituted student engagement. Developed inside a conservative framework of understanding the purposes of schooling, my definitions of student engagement in turn informed my perception of resistance as being defiance or a challenge directed to or at me/the teacher. Over time, I came to understand that my own social privilege was a significant contributor to my views of resistance as negative. As a White, middle-class child who grew up in a family with Christian-based values and beliefs, a family that placed a great deal of emphasis and value on schooling, I saw people like me everywhere in school. I, or someone like me, was represented in the faces of my teachers, in the textbooks and the formal curriculum, in the practices and the policies of school. My own centrality to the processes of schooling meant that I never questioned whether another student might see their own position vis-à-vis schooling processes differently. There was no reason for me to question acts of resistance as anything other than an individual choice. As a student, I came to believe that resistance was something that was done by a "bad kid." I understood resistance

(C) Copyright 2006. The author, Valda K. Leighteizer, assigns to Paideusis the right of first publication and educational and nonprofit institutions a non-exclusive license to use this document for personal use and in courses of instruction provided that the article is used in full and this copyright statement is reproduced. Any other usage is probibited without the express permission of the author. 
within a binary framework: "good kids" were compliant, submitted to and/or supported the authority of the teacher; bad kids were resistant to and/or defiant of the teacher's authority. That belief grounded an understanding that my job as a teacher was to quell resistance directly through intervention, or indirectly by developing strategies to engage the resistant students (i.e. to bring them back into compliance). However, this kind of good kid/bad kid framework for understanding engagement and resistance does not adequately or accurately represent the complex interconnections between these two phenomena. Therefore, as I argue here, we need a less limiting conceptualization of resistance.

This paper outlines my own journey to reconceptualizing resistance. I begin by sketching a picture of the idealized or normative student body, the assumed child for and upon whom schooling practices are based. I then explore the usefulness of Foucault's approach to understanding power and resistance. Understanding power and resistance as relational processes opens the space to consider how these two processes are connected to classroom practices and processes. My exploration of Foucault's work in turn leads to a brief discussion of contemporary understandings of student engagement as it is connected to particular ways of behaving or being in the classroom. Finally, I argue that for some children/students, resistance may be a rejection of cultural colonization (McLaren, 1989) and in some instances, resistance can therefore be argued to be of positive benefit to both teacher and student.

\section{The "Normalized" Child}

As I have noted above, and argued elsewhere (Leighteizer, 2002), schooling practices and processes are predicated upon the assumption of the attendance in schools of a normalized and idealized student body. The idealized student is the child who is identified as privileged within social identity categories: he (for male is one of the categories of social privilege) is acceptably masculine (as masculinity is understood within dominant culture), is White, middle or upper middle class, able-bodied, intellectually and academically capable or more than capable, heterosexual, raised within a Christian-based faith system (or minimally, is familiar with Christian-based belief systems and does not formally live within a faith system that is non-Christian) (Gaskell, McLaren, \& Novogrodsky, 1989; Connell, 1993; Isoki, 1994; Ghosh, 1996; Adams, Bell, \& Griffin, 1997; Apple, 1998; McIntosh, 1998; Dei, G. J. S., James, I. M., Karumanchery, L. L., James-Wilson, S., \& Zine, J., 2000; Banks, 2001; Leighteizer, 2002).

This child does in fact exist, but is not the only child to come to school. We know that many of the children who come to school do not fit within every one of these identity categories; some may fit all but one, some may fit within none at all, and many children will have some places where they occupy the privileged categories and also some of the marginalized (or less- or not-privileged) categories. Each of us has some place on the continuum of each of these; our students are no different in this regard. Schools were, in our distant past, intended primarily for White, middle and upper class boys, the able-bodied and intellectually capable, Christian sons of the ruling and merchant classes, being readied to take up the reins of their fathers' works. In our current social world, schools are intended for many more children than the idealized child. What is often still true, however, and forms a serious critique of schooling processes, is that many students encounter school from the subject position of being an "add-on." Schooling processes have adjusted their borders to accommodate the Other child, while little at the centre has altered. This additive process (Banks, 1998) frequently results in some students experiencing schooling as a dual process. While some students see themselves completely or largely represented, and therefore have as their primary task the acquisition of information, Other students rarely see themselves represented. Thus, in addition to the acquisition of information, they must also make profound decisions about self and identity. They may choose to try to fit inside the parameters of schools, or they may reject the message of Other-ness. It is one form of this rejection, that of active resistance, that I discuss further on in this paper.

First, however, it is necessary to turn to the works of Michel Foucault on power and resistance to build a foundation for my argument. 


\section{Foucault on Power}

It is necessary here to discuss the influence of Foucault's conception of power relations on my thinking about resistance. While this is not intended as an in-depth explication of Foucault's work in this area, understanding power as a relationship rather than as a commodity is an integral component of this reconceptualization of resistance as a positive and sought-after moment or action. Foucault (1978) had this to say on power:

...the word power is apt to lead to a number of misunderstandings - misunderstandings with respect to its nature, its form, and its unity. By power, I do not mean "Power" as a group of institutions and mechanisms that ensure the subservience of the citizens of a given state. By power, I do not mean, either, a mode of subjugation which, in contrast to violence, has the form of the rule. Finally, I do not have in mind a general system of domination exerted by one group over another, a system whose effects, through successive derivations, pervade the entire social body...these are only the terminal forms power takes (p. 92, italics in original).

Commonsense understandings of power tend to treat power as if it were a tangible thing, a commodity to be obtained, or a capacity imbued in a specific position or attached to a particular agent. As a result, conversations about the uses, abuses, and implications of power tend to follow patterns which either implicitly or explicitly assume that power is something that is held, withheld, shared, resisted, or controlled by some individual or collectivity, and to see this as an element of a structure that is imposed on given contexts from outside those contexts themselves. Within this framework, power is understood as invested in particular positions (such as a president, prime minister or teacher) or as emerging from the rules or laws attached to a given social context. Thus, power appears to operate from outside of particular individuals, to shape lives by (ultimately) limiting possibilities. While I am not suggesting that the operations of power do not have these particular effects, I am suggesting that this kind of commodified or static understanding of power is limiting.

This approach to understanding power is a juridico-discursive model (Foucault, 1978). "All the modes of domination, submission, and subjugation are ultimately reduced to an effect of obedience" (Foucault, 1978, p. 85) in this model. Thus power is understood to always reside outside the individual and imposes limits on the individual by setting out what they cannot/should not do, say, want, need. While this kind of "nay-saying" certainly does appear in some aspects of the operations of power relations (we do have authorities, rules, regulations, policies, laws, and a number of similar social processes), Foucault suggests that this is not all that is going on with respect to power. He argues for an analytics of power, i.e., a strategy for understanding power which permits us to appreciate the multiplicitous connections between ideas, relations, and social processes that constitute and/or reflect power relations. Foucault's approach draws our attention to the operations of power relations as a productive rather than a repressive force

Power understood as a commodity is frequently perceived as something one can have, can share, and/or can take away. Power that can be held can also be withheld, can be wielded, often with a view to ensuring that someone behaves in particular kinds of ways. Power understood as a relation, however, opens the possibility of perceiving that one person alone cannot and does not actually possess in tangible form this thing called power. Alone, isolated, I cannot force or influence another to behave as I wish they would. It is only when I am in relationship with another that I have any possibility of influencing them. It is this possibility of influence that provides the definition of power relations, as Foucault (1986) suggests:

What defines a relationship of power is that it is a mode of action which does not act directly and immediately on others. Instead it acts upon their actions: an action upon an action, on existing actions or on those which may arise in the present or the future (p. 220). 
In this sense, power is everywhere, operating at different levels and from different angles in all interactive contexts. Thus, "[p] ower is everywhere; not because it embraces everything, but because it comes from everywhere" (Foucault, 1978, p. 93). The operations of power relations become visible in and through their tangible effects (such as learning to sit quietly and listen while the teacher speaks). The relationship between teachers and students fits Foucault's definition of a relationship of power exactly. After all, the point of schooling is to produce particular kinds of actors in a given social context.

As Foucault points out, wherever power relations exist there is also the possibility for resistance. And just as the relations of power operate from multiple angles simultaneously, strategies for resistance also emerge from multiple points in this relational process. Understanding power and resistance as processes offers us the possibility to perceive that we are never really outside these interconnecting processes. Power and resistance can be understood as simultaneously co-existing relational processes, rather than as binary, oppositional forces. Foucault (1980) argues that "there are no relations of power without resistances; the latter are all the more real and effective because they are formed right at the point where relations of power are exercised" (p. 142).

Treating power as a commodity may give us an understanding that a teacher/educator can, through persuasion or force or will or their own personality, or by wielding their power-over, dictate to a large degree exactly what happens in a classroom of students. And, to some extent, this does happen. Teachers can persuade, require, dominate, or enforce particular ways of behaving, speaking, and of being in a classroom on the part of their students, should the teacher wish to so do. But a teacher cannot do anything much with, to, or for a student if the student is not present, either physically or emotionally or intellectually. Compliance on the part of a student may be surface only, if it is even that.

Treating power as a relationship opens the possibility for understanding that if a student responds to me thus, $\mathrm{s} / \mathrm{he}$ is responding to me, and that means that we are in this moment in relationship with one another. And when we are engaged in relationship with another, then our possibilities, although not limitless, are still open. The quality of the interaction is not necessarily the question under discussion here, but rather, the relationship as a process. In a relationship, we have possibilities for interaction, discussion, or changes of direction that are not necessarily available to us if our conceptualization of power is as a commodity to be wielded, rather than a relationship to be pursued and developed.

This relational approach to understanding power and resistance opens the space to perceive the interconnections between all of the constitutive elements in the pedagogic setting. Administrators, teachers, students, parents, and all of the other players interact inside social and political contexts which also impact on the form and content of the interaction patterns. Within this context the very terms that we use to talk about issues such as engagement, resistance and power are linked to one another in their own relations of power.

\section{Student Engagement}

Student engagement is a social process that becomes visible in its effects. Essentially an interactive concept, it defines and shapes relationships between students and teachers. Engagement is about relationship(s). Students are engaged with someone or something: other students, a teacher, a concept, a project, or resistance/rebellion. Student engagement tends to be discussed as a positive phenomenon (in contrast to disengagement) with definitions of engagement used to provide the implicit or explicit parameters of resistance, rebellion, or disengagement.

Conceptualizations of student engagement range from specific activities or achievements (Jones \& Jones, 2001), to ideas or idealizations of democracy (Shor, 1992; Goodman, 1992; McLaren, 1994; Levin, 1994; Armstrong \& McMahon, 2002), belonging (Roland Martin, 1992; Lee, 1998), or safety (hooks, 1994). As Fred Newmann (1986) observed, "engagement is difficult to define operationally, but 
we know it when we see it, and we know it when it is missing" (quoted in Smith et al, 1998, p. 7). Smith et al (1998) point out that "[t]here is no generally accepted definition of student engagement but from the work of various authors, we gleaned two principal strands of engagement: individual investment and collaboration with others" (p. 2). These two "strands" of engagement are reflected in some of the common themes in discussions of student engagement: commitment to one's work, and/or academic and/or school life; activity; a sense of belonging; learning that is meaningful or relevant. Engagement cannot be limited to some quantifiable or performable element(s), such as good grades or good behaviour. Rather, engagement is a quality of mind, an interactive process visible in its effects rather than in and of itself. It is a category that has elastic edges rather than rigid boundaries.

In identifying characteristics or components of student engagement, much of the literature (while perhaps disagreeing on strategies for implementing belonging-ness) suggests that in order to be engaged in school, students need to feel that they belong (see, for instance, Finn and Voelkl, 1993; Roland Martin, 1992). Students who are racially visible and/or students who are poor may feel alienated from schools because, for the most part, schools have little or no material connection to their lives (Stein, 1971; Kozol, 1991; Dei, Mazzuca, McIsaac, \& Zine, 1997; Nieto, 2000). Understanding the effects of poverty or racism are not the only material elements missing in the construction of many school communities. There is an extensive list of students whose lives are frequently excluded from school communities, and from both formal and informal curriculum: gay, lesbian, or bisexual students; students with a disability; children with learning or behavioural "problems" (Heron, 1983; Wells, 1990; Curtis, Livingstone, \& Smaller, 1992; Uribe \& Harbeck, 1992).

When "school-life" and "out-of-school life" are disconnected from one another, students whose lives are marginalized or absent from school must find ways of negotiating school-life safely, if they are to remain. It was in thinking about these interconnected processes that I started to wonder: if, as I have argued, schooling is about one child, what happens to the child who is Other? It seems to me that the Other child is faced with two possibilities. They may accept the messages of schooling, that they do in fact constitute an Other, and make sense of their world by attempting to fit themselves inside this illfitting picture, which may be a form of cultural colonization (McLaren, 1989). Or, they may reject this message, resisting the information of school, which, while showing up as resistance, is in actuality a form of care taking of the self, a rejection of cultural colonization. To say "I am not" is not passive, nor is it silent: it is a very active rejection to a specific request or requirement that they alter their identity in ways that might make everyday life in school more comfortable for some, but pose a danger to themselves.

\section{Resistance as Engagement}

Bringing all of these discussions together, what intrigues me is that rarely is resistance by a student viewed as a form of engagement. And yet, when a student defies us, challenges our words, or in some way engages in an active form of resistance in our classroom, it is reasonable to state that in order to have done so, that student must first have been paying attention to us. If I challenge what someone has said to me, I must first have heard what they said; if I respond to someone's behaviour or a request from them that I do a certain thing, I must (regardless of how it is that I respond) first have noticed what they were doing or asking of me.

Note that the phrase I employed above was "active resistance." I do not in any way mean to imply that all forms of resistance be seen as forms of engagement. Some students in our classrooms will resist us, what we are doing or saying, for complex reasons of their own that may have nothing to do with an active engagement with our discussion or request. Some students in our classrooms may be silent, or silenced, or physically present while emotionally or intellectually absent (see, for instance, Michelle Fine's (1987) discussion of Patrice). And while these may well also be forms of either active or passive resistance, they are not, at that moment, the kind of resistance of which I am speaking when I 
suggest that some kinds of resistance may also constitute a form of engagement. In some classrooms that have as their focus teaching for social justice, some students who are privileged may actively resist the critique of systemic operations of power and privilege. While theirs is certainly an active resistance, it does not take place as a rejection of cultural colonization. These resistant privileged students are not threatened with having their culture or life experiences negated. It is not their active resistance to which I refer here. Rather, it is the active resistance of students who are socially marginalized, for whom to not resist is more dangerous to self than resistance may be.

In his article entitled I won't learn from you, Herbert Kohl (1994) discusses a phenomenon he names not-learning. He distinguishes not-learning from a failure to learn. A failure to learn, he suggests, might be applied to a student who is not able, for any of a variety of reasons, to interact successfully with the materials of school. Not-learning, however, is a very active refusal to learn specific information taught in school. Not-learning might be employed to refuse racist or sexist language or information taught in schools. Not-learning, in these and other instances, is a healthy response.

In many instances, some resistance of students is indeed an attempt to negate a cultural colonization, a form of safe-keeping of self that requires that some aspect (or all aspects) of schooling be held at bay, for to accept what is being said or done may constitute an active danger to one's own sense of self, an erasure of one's life and experiences. If, as I have argued above, and others have also argued, schooling is predicated on one child, what options are there for children who are "other than" the child who is at the centre of schooling processes? They may comply, and find ways to negotiate the difficult terrain that is theirs: to not only master the content of schooling, but to do so while simultaneously making sense of their own absence in school processes while they themselves are present within the school itself. This, as those who attempt this dual negotiation are aware, is an exhausting task. Or, the Other child may be absent physically, emotionally, or intellectually, in terms of academic success. This is often to their ultimate jeopardy, even if it more adequately ensures their current well-being. They may be the silent child, causing no trouble, slipping through their school years largely unnoticed, to leave before graduating, or to finally graduate with fewer prospects for employment or further education than they might have had if they had been able to participate more actively in their schooling without danger to self accompanying that participation. Or, they may not be silent at all. They may be the vocal student, a student who protests, who argues, who questions: us, their textbooks, the world they live in. In short, they may be the student who resists, and this is the student of whom I speak when I say that some resistance may actually constitute a form of student engagement, and not be a negative action at all. This resistant student, while not compliant, is very actively engaged.

\section{Conclusion}

Some students come to understand that schooling is not about them. They do not see themselves reflected in the faces of their teachers, in their textbooks, in the practices, policies, and processes of schools. Some students are silenced - perhaps especially - when they resist the cultural colonization that would ensue if they were to accept some of the content that directly negates or erases or contradicts their own lives. Faced with such a dilemma, how is it ultimately possible that they will stay in school, or return to school if they leave before finishing, or remain emotionally, spiritually, and intellectually safe, whole, and celebrated if they do stay in school?

Using a relational understanding of power, resistance, and student engagement provides us with a foundation for building a less rigid definition of what constitutes engagement and/or resistance. By opening ourselves to a fluid concept of student engagement, one that views resistance through a lens of possibility, we can question a student's action and our own response to it. We can inquire whether this resistance might be a rejection of cultural colonization, if it might be a resistance necessary for the 
student. We can allow for the possibility that this resistance might be a moment to be nurtured and celebrated instead of firmly and unequivocally ended.

I have argued in this paper for a reading of the processes of student engagement, power, and resistance that may open the space for understanding some kinds of active resistance to the processes of subjection within the systemic operations of privilege and marginalization as both positive and engaged. I argued that understanding power as a relational process opens that space to understanding the effects of power relations without necessarily limiting our expectations that submission or obedience are necessarily good things or that resistance is either necessarily bad or futile.

\section{Acknowledgments}

Some of the ideas and work developed here came from my doctoral thesis, entitled Springboards or Boxes? Theorizing a Social Justice Pedagogy, and once again I thank my committee who gave so much of themselves during that time. In addition, some of the ideas developed here were presented in a conference paper at Congress 2003, held at Dalhousie University in Nova Scotia. I thank the audience members who were present at that conference and who engaged me in a dialogue about my ideas that have helped to continue my development of this work on reconceptualizing resistance and engagement.

\section{References}

Adams, M., Bell, L. A., \& Griffin, P. (Eds.) (1997). Teaching for diversity and social justice: A sourcebook. New York: Routledge.

Apple, M. W. (1998). Teaching and technology: The hidden effects of computers on teachers and students. In L. E. Beyer \& M. W. Apple (Eds.), The curriculum: Problems, politics, and possibilities (pp. 314-336). Albany, NY: State University of New York Press.

Armstrong, D. \& McMahon, B. (2002). Engaged pedagogy: Valuing the strength of students on the margins. Journal of Thought, 37 (1), 53-65.

Banks, J.A. (1998). Approaches to multicultural curriculum reform. In E. Lee, D. Menkart, \& M. Okazawa-Rey (Eds.). Beyond heroes and bolidays (pp.74-75). Washington, DC: Network of Educators on the Americas.

Banks, J. A. (2001). Cultural diversity and education: Foundations, curriculum, and teaching. Needham Heights, Massachusetts: Allyn \& Bacon.

Connell, R. W. (1993). Schools and social justice. Toronto: Our Schools/Our Selves Education Foundation.

Curtis, B., Livingston, D. W., \& Smaller, H. (1992). Stacking the deck: The streaming of working-class kids in Ontario schools. Toronto: Our Schools/Our Selves Education Foundation.

Dei, G. J. S., James, I. M., Karumanchery, L. L., James-Wilson, S., \& Zine, J. (2000). Removing the margins: The challenges and possibilities of inclusive schooling. Toronto: Canadian Scholars' Press Inc.

Dei, G. J. S., Mazzuca, J., McIsaac, E., \& Zine, J. (1997). Reconstructing "drop-out": A critical ethnography of the dynamics of Black students' disengagement from school. Toronto: University of Toronto Press.

Fine, M. (1987). Silencing in public schools. Language Arts, 64 (2), 157-174.

Finn, J.D. \& Voelkl, K.E. (1993). School characteristics related to student engagement. Journal of Negro Education, 62 (3), 249-268.

Foucault. M. (1978). The history of sexuality, volume 1: An introduction. (R. Hurley, Trans.) Toronto: Random House.

Foucault, M. (1980). Powers and strategies. (C. Gordon, Trans.) In C. Gordon (Ed.) Power/knowledge selected interviews and other writings (pp. 134-145). New York: Pantheon Books.

Foucault, M. (1986) The subject and power. In H. Dreyfus and P. Rabinow (Eds.), Michel Foucault: Beyond structuralism and hermeneutics. London: The Harvester Press. 
Gaskell, J., McLaren, A., \& Novogrodsky, M. (1989). Claiming an education: Feminism and Canadian schools. Toronto: Our Schools/Our Selves Education Foundation.

Ghosh, R. (1996). Redefining multicultural education. Toronto: Harcourt Brace \& Company, Canada.

Goodman, J. (1992). Elementary schooling for critical democracy. Albany, NY: State University of New York Press.

Heron, A. (Ed.) (1983). One teenager in 10: Writings by gay and lesbian youth. Boston: Alyson Publications.

hooks, b. (1994). Teaching to transgress: Education as the practice of freedom. New York: Routledge.

Isoki, S. (1994). Present company excluded, of course. In C. E. James \& A. Shadd (Eds.), Talking about difference: Encounters in culture, language and identity (pp. 63-71). Toronto: Between the Lines.

Jones, V. F. \& Jones, L. S. (2001). Comprehensive classroom management: Creating communities of support and solving problems. Toronto: Allyn and Bacon.

Kohl, H. (1994). "I won't learn from you" and other thoughts on creative maladjustment. New York: The New York Press.

Kozol, J. (1991). Savage inequalities: Children in America's schools. New York: Harper Perennial.

Lee, E., Menkart, D., \& Okazawa-Rey, M. (Eds.). (1998). Beyond heroes and holidays. Washington, DC: Network of Educators on the Americas.

Leighteizer, V. K. (2002). Springboards or boxes? Theorizing a social justice pedagogy. Unpublished doctoral dissertation, Dalhousie University, Halifax, Nova Scotia.

Levin, B. (1994). Democracy and education, students and schools. Paper presented at the conference "Under scrutiny again: What kind of secondary schools do we need?" Simon Fraser University, Vancouver, British Columbia.

McIntosh, P. (1998). White privilege: Unpacking the invisible knapsack. In E. Lee, D. Menkart, \& M. Okazawa-Rey (Eds.), Beyond heroes and holidays (pp. 79-82). Washington, DC: Network of Educators on the Americas.

McLaren, P. (1989). Life in schools: An introduction to critical pedagogy in the foundations of education. New York: Longman.

McLaren, P. (1994). Life in schools: An introduction to critical pedagogy in the foundations of education (2nd ed.). White Plains, New York: Longman Publishing Group.

Nieto, S. (2000). Affirming diversity: The sociopolitical context of multicultural education (3rd ed.). Don Mills, Ontario: Longman.

Roland Martin, J. (1992). The schoolhome: Rethinking schools for changing families. Cambridge, MA: Harvard University Press.

Shor, I. (1992). Empowering education: Critical teaching for social change. Chicago: The University of Chicago Press.

Smith, W.J., Butler-Kisber, L., LaRocque, L.J., Portelli, J.P., Shields, C.M., Sturge Sparkes, C., Vibert, A.B. (1998). Student engagement in learning and school life: National project report. Montreal, Quebec: Office of Research on Education Policy, McGill University.

Stein, A. (1971). Strategies for failure. Harvard Educational Review, 41 (2), 158-204.

Uribe, V. \& Harbeck, K. M. (1992). Addressing the needs of lesbian, gay, and bisexual youth: The origins of Project 10 and school-based intervention. In K. M. Harbeck (Ed.), Coming out of the classroom closet: Gay and lesbian students, teachers and curricula (pp. 9-28). New York: Harrington Park Press.

Wells, S. E. (1990). At-risk youth: Identification, programs, and recommendations. Englewood, CO: Teacher Ideas Press.

\section{About the Author}

Valda Leighteizer has graduate degrees in Sociology and in Education (Counselling), and a $\mathrm{PhD}$ in Education. She teaches in both undergraduate and graduate teacher education programs, and her work 
focuses on curriculum theories, social issues (especially as pertaining to schooling processes), and on teaching for social justice. Email: valda.leighteizer@msvu.ca 